\title{
Of tissue blocks and higher anatomy: A typical day in the life of a BSc (Anatomy) student
}

\author{
W. Njongo, P. Gatonga, B. Njihia and C. Masaki, BSc Anatomy students, Department of Human \\ Anatomy, University of Nairobi, P.O. Box 30197-00100, Nairobi, Kenya \\ Correspondence and reprint requests to: \\ W. Njongo, Department of Human Anatomy, University of Nairobi, P.O. Box 30197-00100, Nairobi, Kenya \\ Email: wnjongo@gmail.com
}

A chance to slow the frenetic pace of the day that was, I shed my shoes and slip into the sweet embrace of my blankets. With one eye and a tired thumb I key in '6.30 AM' into my alarm...'Wishful thinking' I say to myself. Halfway through my muttered prayers I succumb, sleep the only respite life has gifted me. Tomorrow shall be yet another day...yet another opportunity to learn.

It starts as a typical Monday... all Mondays do - the frantic typing that fills the air, reminiscent of a typing press. Be it a literature review or the presentation for the afternoon class, the innocent bystander may wonder why after an entire weekend, it would seem we have been caught off-guard. Well, that in itself is another story altogether. Saturday had its fair share of tissue processing to beat the class coordinator's deadlines. Sunday was the opportunity to break away, go to church and then share lunch with friends. Somehow time seemingly slips through your fingers with such an itinerary. Higher anatomy... now that is something novel: one would be forced to wonder how, with our great all-surpassing cranial capacity, the common domestic fowl possesses more efficient respiratory mechanisms. A chicken can breathe better than I can? Yes... even though you are the prey and they are the hunted. Anyway I digress...

With steely resolve the presentations are ready for the day, the drafts ready for scrutiny by the supervisor's keen eye. Hardly has that been done, than we grab our stationery and make headway to the Vet block: 'Quantitative Methodology' they call it... if $u$ ask me I'd rather stick with 'Stereology'. Within 7 minutes of the lecture, I am already exercising my cervical muscles in a bid to remain alert. The facilitator gives that all-knowing smile as he says "You look tired today... eh?" All we can do is nod ...the fleeting glances at the insides of our eyelids offering but a brief recompense for our tired eyes.

After learning about enumerating methodologies in biological systems one can imagine what hunger pangs I face. 'But you just had breakfast' you pipe, to which I'd retort 'What breakfast!' 'I am hungry and so as primal man, I lead the way to the lecturers' Café to have some bitings'. You'd now be thinking... impressive ...but I assure you, for a student eating at lecturer's rates, it's not a bed of roses. What is my consolation? The food is fingerlicking! 'Remember though, more proteins, less carbohydrates is the key to surviving an afternoon!'

There are certain advantages that come with planning your day before hand but then again, there are few experiences that can match the sheer rush of adrenaline when a call comes in: "Is 1.30 ok? We can see some results? ". It's almost comical seeing me bound up the stairs, two at a time, heading to the histology lab. A look at the drying oven confirms my worst fears, but I can almost swear I had some tissues in here... honest! Time to save face though, not to have a pity party. I fling open 
the tissue refrigerator and grab some blocks..' These will have to do' I think to myself. They call it diligence in the world out there...I call it necessity. Before you can say 'Rattus rattus' I have managed to microtome a few decent slides and they are floating on the water bath, in the process securing myself a bloody nick thanks to my fervency. This leaves me with just enough time to scurry down for the afternoon lecture.

Today's turns out to be quite interesting. Best thing about these sessions is that they are more like discussions rather than the stereotypical 'lecturer-come-give-lecture-go' routine that we experienced during the pre-clinical years. Back to our respiratory analogy (remember just a few paragraphs ago when you sat to ponder how your prey can be more efficient than you? Yes...) as we present our widelyresearched accounts the facilitator chimes in with the interjectory 'Why do you think that would be the case?' Humbling experiences these can be! In the middle of my discourse about the possible evolutionary trend in the thoracic wall assembly, Dr. So-and-so has strutted in... most likely he came to say hi or ask for results... but this presentation (for some strange reason... sadism I surmise) intrigues him. It is not long before his contributions to the humbling inquiry are voiced. After the barrage of questioning (more like firing squad I feel) I gladly pass the hot seat on to my colleague. 'Good luck' I mutter under my breath. Truth be spoken, he needed it, for right smack in the middle of his treatise on 'Energy conservation mechanisms in respiration' the proverbial Pandora's Box is opened. To add 'insult' to the heated discussion, almost like on cue, two lecturers stroll in and think 'Oh what a great opportunity to learn science!' I almost feel sorry for my colleague... this mimics a viva session during exams with interjections and postulations being thrown into the melee. All's well that ends well... we all breathe a sigh of relief - it has been a productive day in class, lessons learnt, confidence built.

It's $5.30 \mathrm{pm}$ and I think to myself... my boys should be playing soccer down at the campus fields. 'Sinews' the poet Kipling would have called them - 'biceps' suffices for me. There seems to be an almost inherent predisposition to pack the odd one-or-two inches around the middle in this place. Trust me I almost had those slightly love handles until I decided to take back my form (but do I say...). The match proves to be a wakeup call that I indeed need to continue more along these lines, in fact I should even consider a morning jog (highly unlikely, though it does feel good to think big doesn't it?) After a good pant I make headway back to the hostels and freshen up. 'It's going to be one of those nights' I think to myself.

After fumbling with the keys to our stately office (one learns to derive satisfaction from these little pleasures, you know!) I am shocked to find my colleague (the same fellow who faced the firing squad) still seated at his desk. "Dieting again, aren't we?" I ask. Turns out he had some pending work to submit before the night is over. As I sit, ready to console him, albeit superficially, with a similar story, in walks my supervisor. He seems to be in high spirits and so he proceeds to sit down and give us a breakdown of his lap cholecystectomy on an elderly lady. Our sit-down goes on to tackle rising inflation rates, the seeming indifference in clinical practice and Obama's chances of clinching the Presidency. All this talking has to get your stomach asking for recognition and so it is a welcome relief when he suggests we go out to dinner.

Mexican... Indian... Chinese... Ethiopian... or just plain ugali, sukuma and did someone say Quail? We are really up for anything! These are the opportunities we have to exercise our tongues and palates: redirect our energy to less mind-consuming activities. The evening is a blast... we are dropped back in campus at around midnight. Back to our office... back to deadlines and adrenaline. The 'Discussion' in my term paper must be rewritten and so I get down to work.

As I walk back to the hostels with a tail wind that nips at the tips of my nose and seeks to enjoin my toes in frost-bite I reflect on the finer things in life. I remember that tomorrow I have a meeting with several of my mentees just to chart the way forward in this quarter. Exams are coming up you know. At last I've arrived at my door, my numb fingers struggling to 
open the jammed lock. A chance to slow the frenetic pace of the day that was, I shed my shoes and slip into the sweet embrace of my blankets. With one eye and a tired thumb I key in '6.30 $\mathrm{AM}^{\prime}$ into my alarm... 'Wishful thinking' I say to myself. Halfway through my muttered prayers I succumb, sleep the only respite the day has gifted me. Tomorrow shall be yet another day...yet another opportunity to learn. 